\title{
IDEAIS DE HOMEM CIVILIZADO VEICULADOS NOS LIVROS DIDÁTICOS DE EDUCAÇÃO MORAL E CÍVICA NA DITADURA CIVIL-MILITAR ${ }^{1}$
}

\author{
Daniele Cristina Frediani Gusmão² \\ Tony Honorato 3
}

\section{RESUMO}

A Educação Moral e Cívica (EMC), enquanto disciplina específica da cultura escolar, recebeu maior notoriedade no Brasil durante os anos da Ditadura Civil-Militar (1964-1985), sendo os seus livros didáticos significativos veículos de disseminação de controles e valores a serem interiorizados pela nova geração brasileira. Nesse artigo apresentamos uma pesquisa a partir de seis livros didáticos da disciplina de EMC que circularam em escolas brasileiras no contexto do regime autoritário: Fontoura (1970); Michalany e Ramos (1970); Moschini, Costa e Mussumeci

\footnotetext{
${ }^{1} \mathrm{O}$ artigo tem por base as reflexões desenvolvidas na dissertação de mestrado "Ideias de Homem Civilizado veiculados nos livros didáticos de Educação Moral e Cívica (1969-1986)”, produzida junto ao Programa de Pós-Graduação em Educação da Universidade Estadual de Londrina (UEL).

2 Universidade Estadual de Londrina (UEL), Londrina/PR, Brasil.

3 Universidade Estadual de Londrina (UEL), Londrina/PR, Brasil.
} 
(1970); Andrade (1971); Santos (1974); e Siqueira e Bertolin (1981). O objetivo consistiu em identificar quais foram os ideais de homem civilizado propagados nos livros didáticos de EMC. Para a organização e análise dos dados, nos valemos como referencial teórico das discussões sobre disciplina escolar estabelecidas por Viñao Frago (2008), Chervel (1990), Goodson (1995) e Cuesta Fernandez (1997); no tocante ao livro didático enquanto fonte para uma escrita da história recorremos aos estudos promovidos por Choppin (2004), Bittencourt (2004), Munakata (2016) e Moreira e Diaz (2017); e para a interpretação dos preceitos de civilidade consideramos os aportes teóricos de Elias (1980; 1993; 1994a; 1994b; 2006). Como resultado o homem civilizado deveria (auto)controlar seus impulsos considerando os códigos de comportamentos e sentimentos morais, religiosos, patrióticos e cívicos presentes nos livros de EMC, particularmente nos conteúdos sobre a formação da personalidade do indivíduo (valores, virtudes, direitos, deveres, hábitos e costumes) e sobre a constituição de configurações sociais (família, escola, igreja, forças armadas, estado nacional).

Palavras-chave: Educação Moral e Cívica, civilidade, livro didático, disciplina escolar, poder.

\title{
THE IDEAS OF CIVILIZED MAN VEICULATED IN DIDACTIC BOOKS OF MORAL AND CIVIC EDUCATION IN THE CIVIL-MILITARY DICTATORSHIP
}

\begin{abstract}
Moral and Civic Education (EMC), as a specific discipline of school culture, received greater notoriety in Brazil during the years of the Civil-Military Dictatorship (1964-1985), and its textbooks were significant vehicles for the dissemination of controls and values to be internalized by the new Brazilian generation. In this article we present a research based on six textbooks of the discipline of EMC that circulated in Brazilian schools in the context of the authoritarian regime: Fontoura (1970); Michalany and Ramos (1970); Moschini, Costa and Mussumeci (1970); Andrade (1971); Santos (1974); and Siqueira and Bertolin (1981). The aim was to identify which civilized man's ideals were propagated in the EMC textbooks. For the organization and analysis of the data, we use as a theoretical reference the discussions about school discipline established by Viñao Frago (2008), Chervel (1990), Goodson (1995) and Cuesta Fernandez (1997); regarding the textbook as a source for a writing of history, we have used the studies promoted by Choppin (2004), Bittencourt (2004), Munakata (2016) and Moreira and Diaz (2017); and for the interpretation of the precepts of civility we consider the theoretical contributions of Elias (1980; 1994a; 1994b; 2006). As a result, civilized man should (self) control his impulses by considering the codes of moral, religious, patriotic and civic behavior and sentiment present in the EMC books, particularly in the content on the formation of the individual's personality (values, virtues, rights, duties, habits and customs) and on the constitution of social configurations (family, school, church, armed forces, national state).
\end{abstract}

Keywords: Moral and Civic Education, civics, didactic book, school discipline, power. 


\section{IDEAIS DE HOMBRE CIVILIZADO VEHÍCULADOS EN LOS LIBROS DIDÁCTICOS DE EDUCACIÓN MORAL Y CÍVICA EN LA DICADURA CIVIL-MILITAR}

\section{RESUMEN}

La Educación Moral y Cívica (EMC), como disciplina específica de la cultura escolar, recibió mayor notoriedad en Brasil durante los años de la Dictadura Civil-Militar (1964-1985), siendo sus libros didácticos significativos vehículos de diseminación de controles y valores a ser interiorizados por la nueva generación brasileña. En este artículo presentamos una encuesta a partir de seis libros didácticos de la disciplina de EMC que circularon en escuelas brasileñas en el contexto del régimen autoritario: Fontoura (1970); Michalany y Ramos (1970); Moschini, Costa y Mussumeci (1970); Andrade (1971); Santos (1974); y Siqueira y Bertolin (1981). El objetivo consistió en identificar cuáles fueron los ideales de hombre civilizado propagados en los libros didácticos de EMC. Para la organización y análisis de los datos, nos valemos como referencial teórico de las discusiones sobre disciplina escolar establecidas por Viñao Frago (2008), Chervel (1990), Goodson (1995) y Cuesta Fernández (1997); en lo que se refiere al libro didáctico como fuente para una escritura de la historia recurrimos a los estudios promovidos por Choppin (2004), Bittencourt (2004), Munakata (2016) y Moreira y Diaz (2017); y para la interpretación de los preceptos de civilidad consideramos los aportes teóricos de Elías (1980; 1993; 1994a, 1994b, 2006). Como resultado el hombre civilizado debería (auto) controlar sus impulsos considerando los códigos de comportamientos y sentimientos morales, religiosos, patrióticos y cívicos presentes en los libros de EMC, particularmente en los contenidos sobre la formación de la personalidad del individuo (valores, virtudes, derechos, deberes, hábitos y costumbres) y sobre la constitución de configuraciones sociales (familia, escuela, iglesia, fuerzas armadas, estado nacional).

Palabras clave: Educación Moral y Cívica, civilidad, libro didáctico, disciplina escolar, poder.

\section{LES IDÉES DE L'HOMME CIVILISÉ VEUILLE DANS DES LIVRES DIDACTIQUES D'ÉDUCATION MORALE ET CIVIQUE DANS LA DICTATURE CIVILO-MILITAIRE}

\section{RÉSUMÉ}

La Educación y Moral civique (CEM), en tant que sujet spécifique de sa culture scolaire, recibió la notoriété de maire au Brésil en los años de la dictadura civile-militaire (1964-1985), siendo SUS libros vehículos éducatifs importants des valeurs y Diseminación commande être intériorisé par la nouvelle génération brésilienne. En nous présentons cet objet enquête una de six disciplines d'enseignement libros de la CEM en circularon escuelas en el contexte Brasileñas autoritaire del régimen: Fontoura (1970); Michalany et Ramos (1970); Moschini, Costa et Mussumeci (1970); Andrade (1971); Santos (1974); et Siqueira et Bertolin (1981). L'objectif était d'identifier quels étaient les idéaux de l'homme civilisé propagés dans les manuels d'EMC. Pour l'organisation et l'analyse des données, nous utilisons comme référence théorique les discussions sur la discipline scolaire établies par Viñao Frago (2008), Chervel (1990), Goodson (1995) et Cuesta Fernandez (1997); en ce qui concerne le manuel en tant que source d'écriture de l'histoire, nous recourons aux études promues par Choppin (2004), Bittencourt (2004), Munakata (2016) et Moreira e Diaz (2017); et pour interpréter les préceptes de la civilité, considérons les contributions théoriques 
d'Elias (1980; 1993; 1994a; 1994b; 2006). En conséquence el hombre debería civilisée (auto) contrôle par rapport à des impulsions en les considérant codes comportamientos y sentimientos Morales, religieux, patriotique civique y présente en los libros EMC, en particulier en los Contenidos Sobre la formación de La Personalidad del individuelles (valeurs, vertus, droits, devoirs, habitudes et coutumes) et sur la constitution de configurations sociales (famille, école, église, forces armées, état national).

Mots-clés: Education Morale et Civique, education civique, livre didactique, discipline scolaire, Puissance. 


\section{INTRODUÇÃO}

A Educação Moral e Cívica (EMC) está presente durante o transcurso histórico da escola no Brasil, preceitos de moralidade e civismo fundamentavam finalidades educativas desde as primeiras ações educativas institucionalizadas. No âmbito escolar, no período imperial fizeram parte dos discursos oficiais a veiculação de preceitos de nacionalidade, bons costumes e valores com vistas a manutenção da ordem e a difusão da civilização entre os alunos (ABREU, 2008). Enquanto disciplina escolar específica a EMC esteve presente desde a Primeira República, quando passou a ser inserida no currículo obrigatório do ensino secundário através da Reforma “João Luiz Alves” (Lei Rocha Vaz) em 1925, sob a alcunha de Instrução Moral e Cívica.

Com o passar dos anos a EMC assumiu modelações diferenciadas no cenário educacional brasileiro, na década de 1930, através de ações do Ministro da Educação Francisco Campos, foi suprimida do currículo escolar integrando-se ao corpo de conteúdos da disciplina de Ensino Religioso. Nos anos que seguiram o Estado Novo a Educação Moral e Cívica compunha conteúdos de ensino de diversas disciplinas escolares e em 1961 foi reintegrada ao currículo escolar brasileiro sob o formato de prática educativa por meio da Lei n. 4024/1961 que promulgava a partir de uma prática multidisciplinar e ações extraclasses a formação de bons hábitos aos educandos (FONSECA, 1993).

Em 1962 os preceitos de moralidade e civismo foram novamente sistematizados no currículo escolar brasileiro sob o formato de uma disciplina escolar denominada Organização Social e Política (OSPB), esta disciplina seria parte complementar do currículo do ensino secundário e teria por finalidade o amadurecimento da personalidade dos alunos através do aprendizado das instituições brasileiras, dos valores e deveres cívicos (FILGUEIRAS, 2006).

Ainda que a discussão de Educação Moral e Cívica estivesse presente em diversos momentos da História da Educação Brasileira, sob formatos e nomenclaturas distintas conforme os currículos escolares de cada estado da 
federação, foram nos anos entre 1960-1980 que essa disciplina obteve maior visibilidade representando uma estratégia societária no âmbito escolar para se fazer inculcar preceitos de civilidades em tempos autoritários. No contexto da Ditadura Civil-Militar (1964-1985), a disciplina de EMC foi empregada como instrumento condicionador do comportamento dos indivíduos com vistas ao enquadramento social dentro de específicos ideais de homem civilizado.

A disciplina de EMC, por meio do Decreto Lei n. 869 (BRASIL, 1969), tornou-se obrigatória em todos os níveis de ensino servindo como uma estratégia de disseminação de controles a serem interiorizados pela nova geração. Como um potente veículo difusor de valores civilizatórios, fez-se o uso dos livros didáticos. Sendo assim, propusemos como objetivo deste artigo identificar quais foram os ideais de homem civilizado propagados nos livros didáticos de EMC (1969-1986), especificamente em seis livros eleitos como corpus documental. A periodização histórica diz respeito ao tempo de criação (1969) e encerramento (1986) da Comissão Nacional de Moral e Civismo (CNMC) responsável por chancelar os livros de EMC.

Como fonte histórica de pesquisa, elegemos seis livros: Princípios de Educação Moral e Cívica, de Amaral Fontoura (1970); Educação Moral, Cívica e Política, de Douglas Michalany e Ciro de Moura Ramos (1970); Educação Moral e Cívica, de Felipe N. Moschini, Otto Costa e Victor Mussumeci; Educação Moral e Cívica, de Benedicto de Andrade (1971); Educação Moral e Cívica, de Theobaldo Miranda Santos (1974); e Atividades de Educação Moral e Cívica, de Antonio de Siqueira e Rafael Bertolin (1981). Estes livros foram adotados em razão de terem circulado nas escolas brasileiras e por representarem uma diversidade da fonte documental específica, pois nesse conjunto de impressos há editoras de alta e baixa expressão no mercado editorial, há autores reconhecidos e outros com menor notoriedade no circuito editorial, assim como há livro compêndio e tem caderno de atividades de exercícios de classe de aula, inclusive com as marcas de uso de alunos. Recorremos também ao livro de EMC em virtude dele ter sido o principal guia de aula do professor dessa disciplina, uma vez que 
não havia licenciatura específica para tal formação docente, logo o professor era compelido a apoiar-se ao livro para executar a sua prática.

Para análise, autores de referência colaboraram (BITTENCOURT, 2004; CHOPPIN, 2004; MUNAKATA, 2016; MOREIRA; DIAZ, 2017) ao abordar o livro didático enquanto fonte para uma escrita da histórica da educação, ao discorrerem sobre o entendimento de disciplina escolar (CHERVEL, 1990; GOODSON, 1995; CUESTA FERNÁNDEZ, 1997; VIÑAO FRAGO, 2008) enquanto elemento da cultura e de seus códigos disciplinares com finalidades nos modos de vida em sociedade. E os aportes teóricos de Elias (1980; 1993; 1994a; 1994b; 2006) também permitiram interpretar preceitos de civilidade ${ }^{4}$ desejados às configurações sociais a serem vividas pelos indivíduos em nome da suposta boa sociedade.

Com base nas fontes históricas e na literatura, foi possível versar sobre a disciplina escolar e o livro didático de EMC como objetos de pesquisa interligados. Bem como interpretar os ideais de homem civilizado difundidos nas escolas durante o período da Ditadura Civil-Militar e que articulam de forma interdependente o desejo de mudança de duas estruturas distintas, mas inseparáveis, o indivíduo e a sociedade.

\section{POR UMA HISTÓRIA DAS DISCIPLINAS ESCOLARES: FINALIDADES EM FOCO}

Os estudos sobre a história das disciplinas escolares enquanto campo de pesquisa passaram a ser alvo de historiadores da área da Educação por volta da década de 1970, impulsionados por novos desencadeamentos estabelecidos pela história cultural e, sobretudo, pela história da cultura escolar. Antes, os estudos inerentes ao currículo e às disciplinas escolares eram rechaçados como questões

\footnotetext{
4 Segundo Elias (1994b), o conceito de civilidade está relacionado a um conjunto de preceitos e regras para a convívio social, tudo aquilo que uma dada sociedade considerou imprescindível ser transmitido, uma espécie de "padrão de comportamento socialmente aceitável" (p. 76).
} 
de menor categoria e se baseavam usualmente pelo aferimento de dados e fatos, distantes de uma perspectiva que os evidenciassem como constructo histórico e social (GOODSON, 1995).

A história das disciplinas escolares delineou dimensões analíticas e investigativas que estão imbricadas sob o universo da cultura escolar. Esta, no entendimento de Julia (2001, p. 10), corresponde ao "conjunto de normas que definem conhecimentos a ensinar e condutas a inculcar, e um conjunto de práticas que permitem a transmissão desses conhecimentos e a incorporação desses comportamentos", sendo assim produto do seu contexto de vigência. Conforme Vinão Frago (2008, p. 175), "a história das disciplinas escolares se localizaria sob o guarda-chuva da nova história cultural e constituiria inclusive para alguns, o núcleo fundamental da cultura escolar”.

A disciplina enquanto categoria de análise envolve, incialmente, cinco principais caminhos investigativos: o primeiro trata-se do estudo da gênese da disciplina - como o sistema escolar seleciona os saberes a serem ensinados e os a serem esquecidos, e como é feita a sistematização dos saberes das ciências de referência em disciplinas escolares; o segundo é sobre o estudo da presença da disciplina - como as disciplinas estão situadas em diferentes tempos e espaços, e como são estabelecidos os pesos e dominações nos planos de estudos; o terceiro corresponde ao estudo das finalidades educativas outorgadas com o ensino das disciplinas - quais as intenções que presidem a disseminação de uma disciplina, quais seus sentidos para a formação almejada dos alunos; o quarto converge para as práticas de ensino - de que forma e método são ensinados os saberes e práticas das disciplinas; e, o quinto está permeado pelo estudo da profissionalização docente - formação dos critérios de seleção para o exercício da profissão, como é estruturada a carreira, como se estabelece a formação de comunidades disciplinares e a sua presença social e institucional (VIÑAO FRAGO, 2008).

Na nossa pesquisa, embora reconheçamos a necessidade de articulação dos cinco eixos para a escrita de uma história das disciplinas escolares, evidenciamos com maior afinco as finalidades outorgadas ao ensino de uma 
disciplina. $\mathrm{O}$ estudo das finalidades educativas demanda compreender o conhecimento escolar enquanto artefato social e histórico suscitadores de objetivos e de relações de poder da sociedade vigente. Para Goodson (1997), as finalidades delegadas a uma disciplina são representantes de um campo de forças resultantes de disputas por supremacia proeminentes de grupos que tencionam legitimidade, pois "os atores envolvidos empregam uma gama de recursos ideológicos e materiais para levarem a cabo as suas missões individuais e coletivas" (Ibid., p. 27).

As finalidades atribuídas à disciplina de Educação Moral e Cívica (19691986) visavam a disseminação de preceitos de civilidade, de patriotismo, de ordem e de segurança nacional destinados às novas gerações em tempos de sociedade democrática de direito condenada pela autocracia. Nesse sentido, a sua organização de conteúdos presente nos livros didáticos evidencia saberes considerados necessários para a formação do novo homem civilizado. Assim os livros didáticos de EMC são representantes das disputas dispensadas para uma disciplina escolar em tempos de Ditadura Civil-Militar no Brasil.

\section{LIVRO DIDÁTICO: INSTRUMENTO DE DIFUSÃO DE VALORES}

O livro didático se caracteriza como portador de saberes acumulados, selecionados e sistematizados por agentes de uma sociedade e a serem ensinados em específicas disciplinas escolares. Em Chartier (1990), ele pode ser apreendido como objeto em circulação devido à sua capacidade de transmitir os anseios da sociedade no que diz respeito à educação. "De modo geral o livro didático é a transcrição do que era ensinado, ou que deveria ser ensinado, em cada momento da história da escolarização" (MUNAKATA, 2016, p. 123).

O livro didático revela traços da cultura societária que o elaborou, ele explicita finalidades de uma disciplina escolar destinada à formação dos 
indivíduos em sociedade. Ao analisá-lo pode-se observar transformações referentes ao contexto sócio histórico, pois faz parte de suas finalidades a difusão e a consolidação de conteúdos e valores socioculturais e políticos que se desejavam evidenciar e praticar em uma determinado tempo e espaço da cultura escolar.

Como objeto escolar, cultural e histórico com características e funções específicas, o livro didático, conforme Moreno (2014), estabelece diversas vinculações com o contexto de sua produção e utilização. Já Bittencourt (2004) propõe quatro categorias de análise indicando possibilidades do livro didático enquanto mercadoria, depositário dos conteúdos escolares, instrumento pedagógico e veículo portador de um sistema de valores, ideologia e cultura.

O livro didático de Educação Moral e Cívica (EMC), enquanto mercadoria, incitou-nos o reconhecimento do papel do governo federal brasileiro na produção, compra, distribuição e comercialização, isto porque era o próprio governo que autorizava, encomendava, financiava, avaliava e distribuía os livros no período histórico eleito por nossa pesquisa. Enquanto depositário dos conteúdos escolares, os livros de EMC tinham em sua organização saberes considerados como imprescindíveis para o exercício do bom convívio social conforme os anseios dos grupos com maiores gradientes de poder em sociedade, entre eles frações de militares, políticos, religiosos e empresários. Como instrumento pedagógico, os livros apresentam atividades e exercícios de EMC objetivando a memorização por parte dos alunos de preceitos, deveres, hábitos e normas. Enquanto um veículo disseminador de um sistema de valores, de ideologia e de cultura, vislumbramos anseios, manifestações, discursos, representações e estratégias pedagógicas guiadas por finalidades sociais, políticas, econômicas e militares que seriam propagadas via a disciplina escolar de EMC.

No período da Ditadura Civil-Militar, os livros didáticos eram subsidiados pelo governo federal por meio de convênios instituídos, por exemplo, entre o Ministério de Educação e Cultura (MEC), a Agência Norte Americana para 
o Desenvolvimento Internacional (Usaid) e o Sindicato Nacional dos Editores de Livros (Snel). Os convênios proporcionaram um significativo aumento da produção, compra e distribuição de livros. Por intermédio dos programas da Comissão do Livro Técnico e do Livro Didático (Colted), outorgada pelo Decreto Lei n. 59.355, de 4 de outubro de 1966 (BRASIL, 1966), realizaram-se a entrega de milhares de livros didáticos às escolas brasileiras, o que alavancou também o mercado editorial.

Em tempos de regime autoritário, o livro de EMC assumiu o lugar de um instrumento de difusão de saberes e preceitos de ordem e nacionalismo que determinados setores com maiores gradientes de poder em sociedade almejavam veicular junto à nova geração de escolares. Por conta disso, os livros estavam sob à apreciação, vigilância e censura dos órgãos governamentais como a Comissão Nacional de Moral e Civismo (CNMC), criada em 1969 e extinta em 1986. Aqueles aprovados representavam um patrimônio cultural a ser conhecido, utilizado e apropriado para a formação do "bom" cidadão brasileiro na disciplina escolar de Educação Moral e Cívica.

\section{A DISCIPLINA E O LIVRO DIDÁTICO DE EMC NA DITADURA CIVIL-MILITAR}

O Brasil foi palco de uma Ditadura Civil-Militar instaurada em abril de 1964, por meio de intervenções, censuras e coações, arquejava-se a legitimação do poder arrasador da democracia e da prosperidade social sob a chancela do binômio Segurança e Desenvolvimento. O golpe liderado pelas Forças Armadas teve a participação de amplos setores civis da sociedade brasileira, pois "banqueiros, empresários, industriais, latifundiários, comerciantes, políticos, magistrados e classe média" (FICO, 2004, p. 3) integravam uma frente social e política que junto aos militares efetivou uma campanha ideológica que efetivou a deposição do então presidente João Goulart (DREIFUSS,1986). 
A compreensão de Ditadura Civil-militar foi empregada neste artigo em razão do reconhecimento da participação da sociedade civil na consolidação do regime vivido no Brasil entre 1964 e 1985. Segundo Reis (2010), a expressão "civil-militar" seria a mais conveniente para caracterizar o Golpe de 1964, em virtude da participação de diversos setores da população brasileira. Para o autor, não reportar a colaboração da sociedade civil brasileira na legitimação da ditadura seria "como tapar o sol com a peneira". Recorremos também ao uso dessa compreensão em virtude dos livros didáticos de Educação Moral e Cívica terem sido produzidos, em geral, por civis.

Assim visando coibir uma suposta ameaça subversiva, o governo utilizouse de "intervenções moderadoras" para coerção e controle da sociedade civil (SAFLATE; TELES, 2010), diferentes instituições se condicionaram a fórceps aos ideais dos grupos com maiores gradientes de poder, sendo a escola um dos exemplos mais evidente desse intervencionismo. A educação escolar sob fiscalização do Estado autoritário, foi condicionada à lógica governamental vigente, por meio dela pretendia-se formar um ideal de homem brasileiro por meio da veiculação de preceitos de civilidade aplausíveis aos anseios da sociedade (REZENDE, 2013).

No intuito de difundir um ideal de homem pacífico e ordeiro e de regular a formação da personalidade da nova geração, propôs-se à cultura escolar a implantação de uma disciplina curricular que trilhasse a criança e o jovem em concordância aos preceitos tidos como civilizados pelo regime autoritário. Assim, os saberes de Educação Moral e Cívica (EMC) tornaram-se obrigatórios em diferentes níveis de ensino (primário, secundário e superior) por meio do Decreto Lei n. 869/1969, o qual atribuía a veiculação e difusão de um conjunto de princípios, deveres, normas, ações e sentimentos nacionalistas a serem edificados na consciência e na vida prática dos alunos.

Art. $1^{\circ}$ É instituída, em caráter obrigatório, como disciplina e, também, como prática educativa, a Educação Moral e Cívica, nas escolas de todos os graus e modalidades, dos sistemas de ensino no País. 
Art. $2^{\circ} \mathrm{A}$ Educação Moral e Cívica, apoiando-se nas tradições nacionais, tem como finalidade:

a) a defesa do princípio democrático, através da preservação do espírito religioso, da dignidade da pessoa humana e do amor à liberdade com responsabilidade, sob a inspiração de Deus;

b) a preservação, o fortalecimento e a projeção dos valores espirituais e éticos da nacionalidade;

c) o fortalecimento da unidade nacional e do sentimento de solidariedade humana;

d) culto à Pátria, aos seus símbolos, tradições, instituições e aos grandes vultos de sua história;

e) o aprimoramento do caráter, com apoio na moral, na dedicação à família e à comunidade;

f) a compreensão dos direitos e deveres dos brasileiros e o conhecimento da organização sócio-político-econômica do País;

g) o preparo do cidadão para o exercício das atividades cívicas com fundamento na moral, no patriotismo e na ação construtiva, visando ao bem comum;

h) o culto da obediência à Lei, da fidelidade ao trabalho e da integração na comunidade.

Parágrafo único. As bases filosóficas de que trata este artigo, deverão motivar:

a) a ação nas respectivas disciplinas, de todos os titulares do magistério nacional, público ou privado, tendo em vista a formação da consciência cívica do aluno;

b) a prática educativa da moral e do civismo nos estabelecimentos de ensino, através de todas as atividades escolares, inclusive quanto ao desenvolvimento de hábitos democráticos, movimentos de juventude, estudos de problemas brasileiros, atos cívicos, promoções extra-classe e orientação dos pais (BRASIL, 1969, p. 2).

Caberia à disciplina de EMC potencializar a formação da personalidade e do comportamento da nova geração brasileira segundo um padrão psicossocial, nacionalista e religioso idealizado pelos grupos fortes na balança de poder compostos, naquele contexto exceção, por membros do alto escalão militar, setores conservadores da igreja católica, proprietários de grande meios de comunicação, empresários interessados no comércio internacional, entre outros.

Ideais de homem civilizado, autorizados e almejados para as finalidades 
das disciplinas escolares, estavam prescritos em forma de conteúdos didáticos presentes nos livros de EMC. Os livros, por interdependência, estavam ligados às diretrizes de organização dos conteúdos da disciplina de EMC previstas em dois documentos significativos, a saber: Subsídios para Currículos e Programas Básicos de Educação Moral e Cívica, documento elaborado pela Comissão Nacional de Moral e Civismo (CNMC) e aprovado pelo Parecer n. 101 de 1970 do Conselho Federal de Educação (CFE); e pelo Programa Curricular da Disciplina de Educação Moral e Cívica, estabelecido no Parecer n. 94 de 1971, criado e outorgado pelo CFE. Desse modo, coexistiram no mínimo duas propostas de currículos escolares para a disciplina de EMC, tal realidade culminou na diferenciação da organização dos conteúdos dos livros didáticos, conquanto, a premissa geral de formação do considerado bom cidadão brasileiro se fazia presente em ambos. Vejamos, no Quadro 1:

Quadro 1 - Subsídios para Currículos e Programas Básicos de Educação Moral e Cívica Ginasial (CNMC).

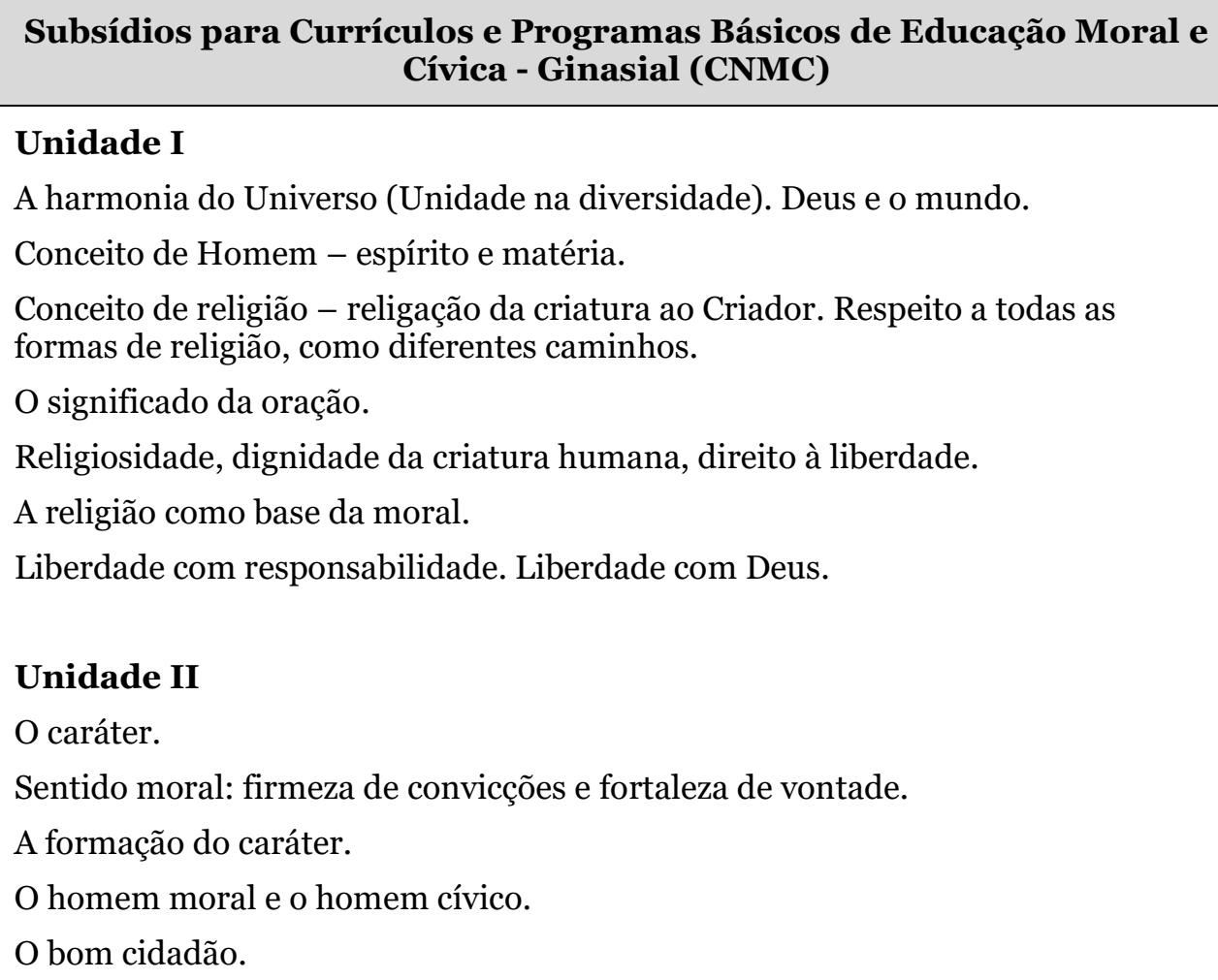




\section{Subsídios para Currículos e Programas Básicos de Educação Moral e} Cívica - Ginasial (CNMC)

Noções de axiologia.

Valores subjetivos e valores objetivos: permanentes e efêmeros.

Escala e hierarquia de valores.

Virtudes morais e virtudes cívicas.

O hábito.

Deveres e direitos morais; deveres e direitos cívicos.

\section{Unidade III}

Elementos básicos da nacionalidade.

A Terra: características e peculiaridades de ordem econômica e social.

O Homem. Os grupos étnicos formadores.

As instituições, características por valores permanentes. Família, Igrejas, Forças Armadas, Instituições Culturais.

\section{Unidade IV}

A Constituição do Brasil.

Suas bases filosófico-teístas, aconfessionais.

Consequências na Educação.

Características jurídicas.

Os três poderes.

Segurança nacional.

Forças armadas.

Direitos e garantias individuais.

A ordem econômica e social.

O trabalho e a propriedade, pressupostos jurídicos do desenvolvimento nacional. A família, a educação e a cultura.

A democracia brasileira, como filosofia e estilo de vida e como regime político.

\section{Unidade V}

A pátria brasileira: ideais, características físicas e históricas.

Vultos nacionais; valores criados que inspiram a ação construtiva.

Os símbolos nacionais: conhecimento e uso.

$\mathrm{O}$ voto e o serviço militar.

O civismo como caráter, patriotismo e ação.

\section{Unidade VI}

Síntese da organização sócio-político-econômica do Brasil. 


\begin{tabular}{|c|}
\hline $\begin{array}{c}\text { Subsídios para Currículos e Programas Básicos de Educação Moral e } \\
\text { Cívica - Ginasial (CNMC) }\end{array}$ \\
\hline $\begin{array}{l}\text { Principais problemas brasileiros e da comunidade. Possibilidades de } \\
\text { participação do educando. }\end{array}$ \\
\hline Relação entre pessoa, família e comunidade. \\
\hline Unidade VII \\
\hline O Brasil e o mundo. Integração no mundo ocidental. \\
\hline Relações internacionais. \\
\hline Unidade VIII \\
\hline Noções das principais estruturas sociais contemporâneas. \\
\hline A democracia, espiritualista; e o comunismo, ateu. \\
\hline $\begin{array}{l}\text { A necessidade de a democracia alicerçar-se em valores espirituais e morai } \\
\text { o uso da liberdade responsável. }\end{array}$ \\
\hline
\end{tabular}

Fonte: Brasil (1970).

Propostos pela CNMC, os Subsídios tinham por finalidade auxiliar a elaboração de programas curriculares para disciplina de EMC e de seus livros didáticos. Suas prescrições evidenciam uma preconização dogmática dos conteúdos da disciplina ligados à moral, religiosidade e patriotismo. Os temas orientados enfatizam o posicionamento ideológico atrelado às convicções da Escola Superior de Guerra e Doutrina de Segurança Nacional (FILGUEIRAS, 2006). Destaca-se que membros da CNMC assumiam seus postos por indicação do Presidente da República e usualmente estavam vinculados à Igreja Católica e à Área Militar.

A CNMC e o CFE dividiam espaços na estruturação da disciplina da EMC. Ainda que o CFE defendesse sua supremacia frente aos assuntos educacionais do país, no âmbito da EMC, a CNMC foi órgão decisivo na implantação e manutenção da disciplina, principalmente na vigilância do comportamento social e validação dos livros didáticos. Contudo, suas regulamentações estavam vinculadas às resoluções do CFE o que acabou ocasionando divisões na veiculação da disciplina (FILGUEIRAS, 2006). Vejamos o Programa proposto pelo CFE, no Quadro 2: 
Quadro 2 - Programa Curricular da Disciplina de Educação Moral e Cívica (CFE).

Programa Curricular da Disciplina de Educação Moral e Cívica (CFE)

Unidade I: O Homem - seus atributos pessoais.

1.1 - Dimensão psicobiológica: "animal racional" análise da personalidade como dinâmica de valores e atributos individuais.

1.2 - Dimensão Ética:

1.2.1 - Consciência;

1.2.2 - Caráter;

1.2.3 - Moral;

1.2.4 - Valores.

1.3 - Dimensão Social: Indivíduo = Cidadão.

1.4 - Dimensão Espiritual:

1.4.1 - Fé;

1.4.2 - Crenças;

1.4.3 - Tradições.

1.5 - Dimensão Cultural:

Indivíduo - Determinada cultura.

Unidade II: O Homem comunitário: seus atributos sociais.

2.1 - Importância da família, da escola e da comunidade, na formação e no fortalecimento dos princípios morais, sociais e culturais e do homem comunitário;

2.2 - Definição sadia de Homem Comunitário, levando os alunos a não confundilo com grupos de pressão que procuram desenvolver atividade política contestatória;

2.3 - As diferentes formas de atividades humanas:

2.3.1 - O trabalho - principais formas e setores;

2.3.2 - Atividades agropastoris;

2.3.3 - Comércio;

2.3.4 - Administração;

2.3.5 - Serviços;

2.3.6 - Lazer;

2.4 - Regras de convivências democráticas:

2.4.1 - Direitos e deveres morais e cívicos;

2.4.2 - Igualdade de oportunidades;

2.4.3 - A responsabilidade do homem na sociedade;

2.4.4 - Legislação;

2.4.5 - Governo; 
Programa Curricular da Disciplina de Educação Moral e Cívica (CFE)

Unidade III: A Terra e o homem brasileiro.

3.1 - As disparidades regionais, estratégias de integração nacional;

3.2 - Raízes étnicas e culturais:

3.2.1 - Elementos formadores: branco, negro e o índio;

3.2.2 - O papel sócio-econômico cultural do imigrante.

3.3 - Eventos e vultos históricos;

3.4 - Tradições religiosas:

3.4.1 - A Igreja, a influência de outros grupos religiosos;

3.4.2 - O espirito religioso no complexo cultural brasileiro.

3.5 - Tradições culturais:

3.5.1 - O folclore e a cultura popular;

3.5.2 - Preservação e expansão das diversas formas de expressão cultural.

Unidade IV: A atual organização político-administrativa.

4.1 - A organização Constitucional Brasileira;

4.2 - A organização política: Elementos Básicos;

4.2.1 - Conceitos, bases e funções:

- Governo;

- Pátria;

- Nação;

- Estado.

Unidade V: Instituições e símbolos nacionais.

5.1 - Forças Armadas - Serviço Militar;

5.2 - Forças Auxiliares;

5.3 - Os símbolos nacionais; o hino; a bandeira; o selo e o escudo.

Unidade VI: A realidade Brasileira.

6.1 - O trabalho e o desenvolvimento nacional:

6.1.1 - Fatores condicionantes do desenvolvimento dos setores primários, secundário e terciário;

6.1.2 - Formas de ocupação produtiva da terra;

6.1.3 - Exploração dos recursos minerais e dos potenciais de recursos hidráulicos.

6.2 - Expansão das oportunidades de emprego:

6.2.1 - O trabalho como um direito do homem e um dever social;

6.2.2 - A harmonia como solidariedade entre as categorias sociais de produção. 


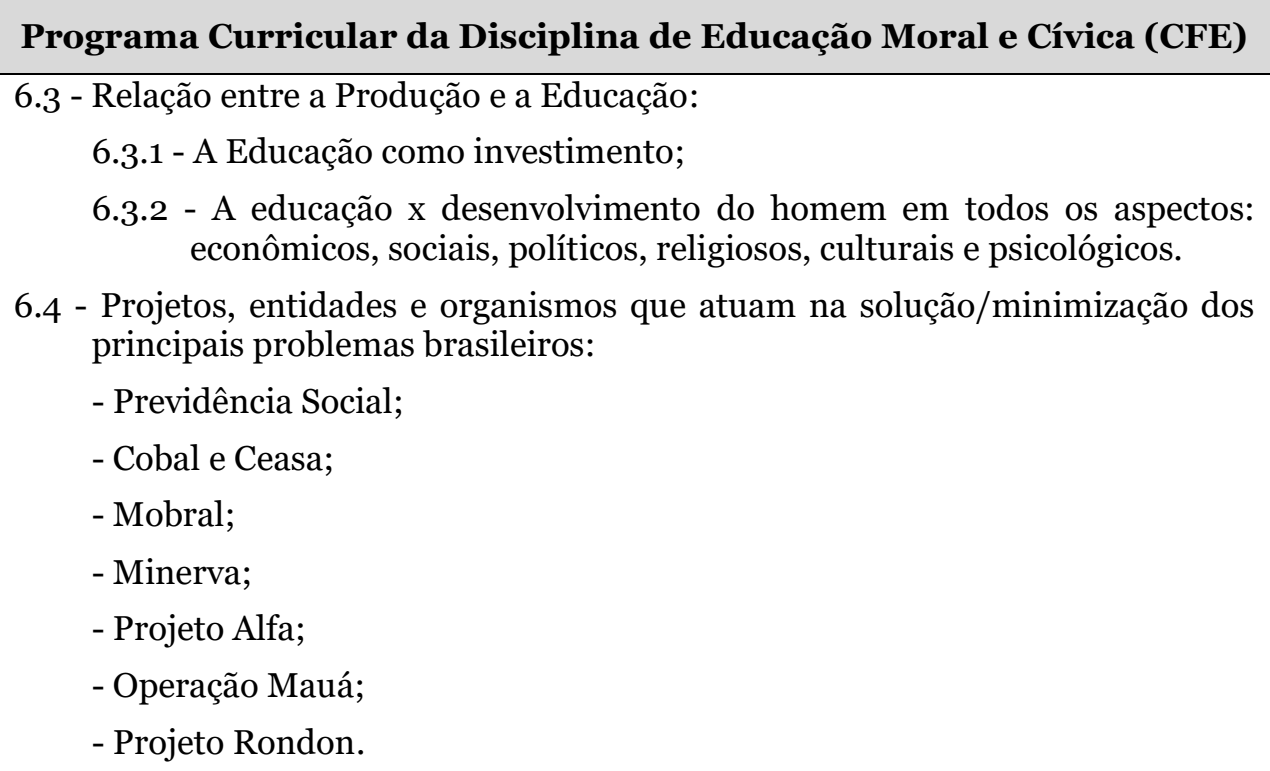

Fonte: Brasil (1971b).

O Programa Curricular proposto pelo CFE, assim como os Subsídios da CNMC, também trazia em sua estruturação conteúdos visando moldar a personalidade da nova geração a partir da incorporação de valores morais, religiosos e cívicos, bem como o cumprimento de deveres para com as instituições. Contudo, o Programa do CFE demonstra menor posicionamento ideológico frente à proposição dos conteúdos, ele discorre sobre temas mais próximos à realidade dos alunos e menos dogmáticos e inflexivos comparados aos temas previstos nos Subsídios da CNMC. Ressalta-se que o CFE foi contrário à obrigatoriedade da EMC como disciplina escolar específica, ele considerava mais viável uma espécie de prática educativa. Essa direção menos incisiva de se pensar a EMC pode ser visualizada em seu currículo (FILGUEIRAS, 2006).

Em geral, os guias curriculares apresentavam conteúdos semelhantes. Contudo, conforme Filgueiras (2006), as orientações curriculares do CFE estavam mais voltadas ao estudo dos problemas brasileiros, enquanto as orientações da CNMC voltavam-se mais aos valores religiosos e de exaltação da pátria.

É fato que os livros de EMC precisavam ser avaliados, autorizados e 
autenticados pela CNMC, para depois serem distribuídos nas escolas brasileiras. Era responsabilidade desse organismo fiscalizar e propagar se os livros encontravam-se perfilados aos princípios de moralidade, civilidade e civismo reclamados pelos setores hegemônicos na sociedade. A seguir, na Figura 1, segue um registro de uma obra aprovada pela CNMC, extraído do livro Educação Moral e Cívica, de autoria de Theobaldo Miranda Santos:

Figura 1 - Aprovação do livro didático pela Comissão Nacional de Moral e Civismo (CNMC).

Obra aprovada pela Comissão Nacional de Moral e Civismo, e homologada pelo Sr. Ministro da Educação, conforme despacho a seguir transcrito:

"Processo n. ${ }^{\circ}$ 100.701/71 - Comissão Nacional de Moral e Civismo - nos termos e para os efeitos do $\S 1 .^{\circ}$ do Art. 10 do Decreto número 68.065, de 14 de janeiro de 1971, homologou o parecer da Comissão Nacional de Moral e Civismo favorável à aprovação do original do livro intitulado "Educação Moral e Cívica", de autoria de Theobaldo Miranda Santos (ficha número 26), do ponto de vista de moral e civismo, Companhia Editora Nacional."

Fonte: Santos (1974, p. 2).

Os livros de EMC foram alvo de vigilância e fiscalização por parte do Estado ditatorial e de setores conservadores da sociedade civil, porque efetivariam em larga escala um poder de difusão de valores e de padrões comportamentais considerados civilizados em tempos de um cidadão forjado e coagido. Para ter êxito, os conteúdos didáticos, mediados pelos livros e pela disciplina de EMC, deveriam provocar de forma interdependente mudanças nas estruturas da personalidade dos indivíduos e nas configurações sociais. Assuntos para os dois próximos tópicos. 


\section{FORMAÇÃO DA PERSONALIDADE DO “BOM" CIDADÃO BRASILEIRO}

Os conteúdos presentes nos livros de EMC eram formados por um compilado de saberes e exercícios práticos que apreendiam os atributos pessoais da formação da personalidade do homem civilizado. Tencionavam-se condicionar os modos de pensar, sentir e viver da nova geração brasileira proeminente Ditadura Civil-Militar. Os conteúdos identificados nos seis livros de EMC analisados por essa pesquisa (FONTOURA, 1970; MICHALANY; RAMOS, 1970; MOSCHINI; COSTA; MUSSUMECI, 1970; ANDRADE, 1971; SANTOS, 1974; SIQUEIRA; BERTOLIN, 1981), diretamente voltados ao indivíduo enquanto unidade a ser transformada para a vida social, são: valores e virtudes, direitos e deveres, hábitos e costumes.

Valores e Virtudes foram indexados como parte obrigatória nos livros didáticos de EMC. O ensino visava a disseminação de um código de sentimentos comuns para inculcar nos alunos padrões comportamentais considerados civilizados e fortalecer a identidade nacional homogeneizante. Por isso, seria nobre o estudante interiorizar preceitos morais, espirituais, intelectuais, cívicos e materiais que estivessem relacionados à tolerância, prudência, perseverança, passividade, obediência, justiça, trabalho, ordem, respeito às autoridades e patriotismo no intuito de manutenção e legitimação do regime autoritário de governo.

Para Andrade (1971), no livro Educação Moral e Cívica, os valores são qualidades que envolvem e despertam interesses nos sujeitos para a disposição de se fazer o bem de forma justa, atingindo a virtuosidade. Segundo Fontoura (1970, p. 147), "as virtudes no sentido moral, são os atributos do Bem, cuja semente foi colocada por Deus na alma humana”. Assim os valores e as virtudes seriam atributos da vida praticada pelas pessoas e relacionados com a vida espiritual dos homens.

Em Atividades de Educação Moral e Cívica (SIQUEIRA; BERTOLIN, 
1981), o homem para ser considerado civilizado deveria apresentar e reproduzir bons comportamentos como cultuar a memória dos grandes homens, respeitar os símbolos nacionais, reverenciar a bandeira, possuir bons atos humanos de cortesia, de defesa, de abnegação e de heroísmo. O homem também deveria se dispor de valores que podem ser sistematizados em seis classes: valores úteis como aqueles relacionados à manutenção da vida dos indivíduos; valores vitais inerentes às exigências e aperfeiçoamento dos indivíduos ou da vida humana, por exemplo civilidade, elegância de maneiras, equilíbrio emocional e traços harmoniosos da personalidade; valores lógicos - alusivos às necessidades de conhecer e explorar em termos científicos o mundo em que vive; valores estéticos - referentes às necessidades de ordem moral e de criação interior; valores éticos - relativos às necessidades de sobrevivência e harmonia do grupo social; e valores religiosos - no tocante ao reconhecimento à ordem divina do mundo e de seu criador.

A estrutura curricular da disciplina e dos livros de EMC, outorgada pelo Parecer n. 101 de 1970 e pelo Parecer n. 94 de 1971, propunha sobre formação da personalidade dos alunos a veiculação do eixo de conteúdos Direitos e Deveres como indispensáveis para o exercício da boa convivência humana. A partir dos direitos e deveres, segundo Almeida (2009), os alunos seriam formados no intuito de cumprir o projeto nacional guiado pelo binômio Segurança (ser pacífico) e Desenvolvimento (ser preparado ao mercado de trabalho).

Enquanto estratégia de poder de objeto cultural de uma época, o livro didático de EMC disseminava os direitos e deveres considerados legítimos pela sociedade autoritária vigente na Ditadura Civil-Militar. Na organização de seus conteúdos continha um corpo de saberes a serem ensinados, metodologias de ensino a serem praticadas.

Siqueira e Bertolin (1981) evidenciam, por meio de exercícios de fixação, direitos e deveres para formação do conjecturado bom cidadão brasileiro (Fig. 2): 
Figura 2 - Direitos e deveres do bom cidadão.

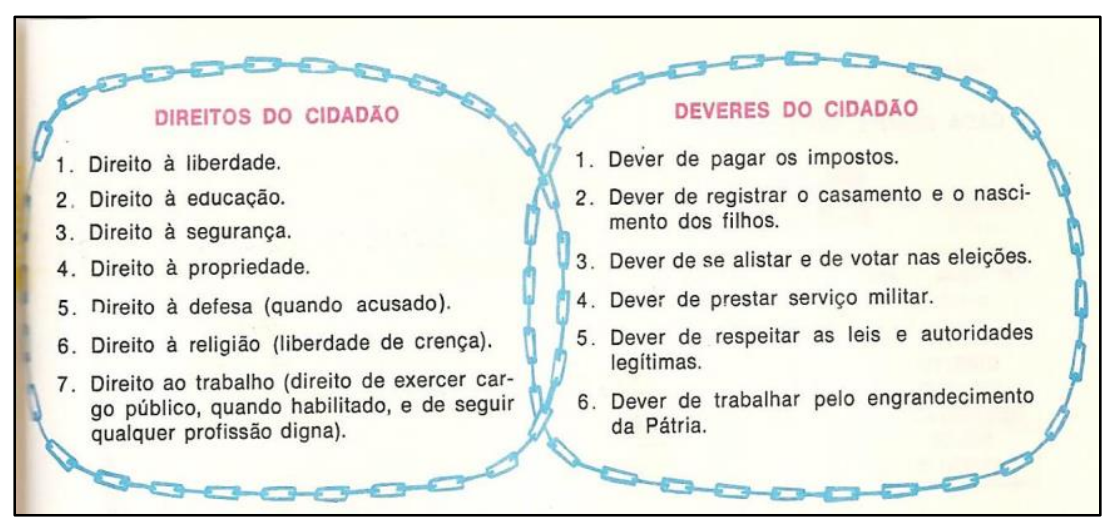

Fonte: Siqueira e Bertolin (1981, p. 39).

Havia um esforço de enquadramento da personalidade dos alunos no entrelaçamento entre obrigações e responsabilidades a serem desempenhadas em relação à Pátria, a Deus, à família, ao trabalho, a si mesmo e à sociedade. Os direitos e deveres eram interdependentes com a doutrina nacional para obter o modo vida ordeiro, espiritual e patriótico.

Para Fontoura (1970, p. 87), em Princípio de Educação Moral e Cívica, o indivíduo "começa a ser cidadão depois de iniciar o cumprimento de seus deveres para com a Pátria: prestar serviço militar, alistar-se como eleitor, cumprir as leis do país". Santos (1974) considera como bom cidadão aquele que cumprisse fiel e integralmente os deveres, para então gozar da plena cidadania.

Hábitos e Costumes também foram conteúdos privilegiados nos livros didáticos de EMC. Para Fontoura (1970), o hábito é uma segunda natureza, algo a ser interiorizado pelos indivíduos e reproduzido naturalmente na vida social. A medida que o indivíduo vai crescendo, a formação do seu caráter dever-se-ia tomando forma direta, criando os bons hábitos do respeito aos costumes convencionados e do cumprimento dos deveres por mais simples ou desagradáveis que fossem.

Em geral, os hábitos e costumes são revelados nos livros de EMC em contraposição aos vícios. Na esfera da orientação religiosa tem-se a ambição, 
soberba, presunção, vanglória, avareza, luxúria, inveja, ira, gula e preguiça considerados como maus hábitos e pecados capitais. Já a higiene, cordialidade, polidez, respeito ao horário e uso de vocabulário adequado eram requisitados pelas esferas escolar, social e pessoal. Em Educação Moral e Cívica, o autor chama a atenção que compete a cada indivíduo a sua própria vigilância contínua na luta contra hábitos nocivos, pois "o homem vale, o que vale seus hábitos" (SANTOS, 1974, p. 29).

Nos livros de EMC para fixar os sentidos de bons hábitos e costumes são comuns textos conceituais e exercícios de memorização por meio de jograis, questionários, ligação de sentenças, complete a frase, palavras cruzadas, dentre outros. Em Educação Moral e Civismo, de autoria de Moschini, Costa e Mussumeci (1970), encontra-se o exercício (Fig. 3):

Figura 3 - Exercícios para fixação de conteúdos acerca dos bons hábitos.

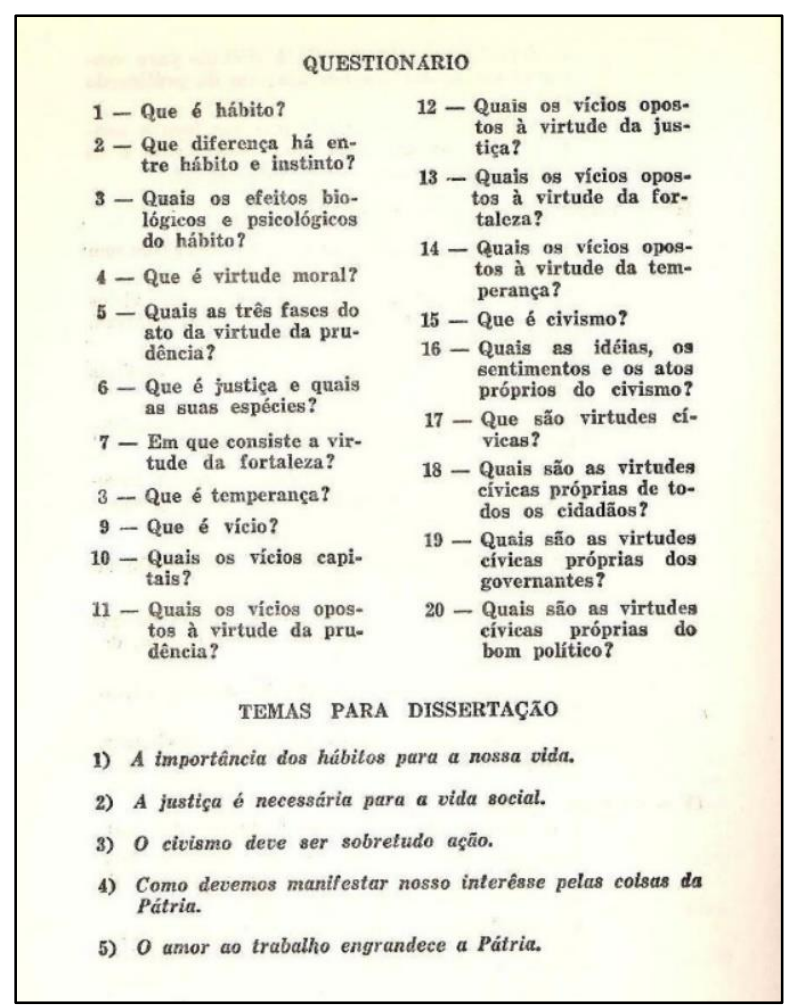

Fonte: Moschini, Costa e Mussumeci (1970, p. 62). 
Ao término de cada unidade de estudo eram apresentados exercícios com vistas a reproduzir os conteúdos ensinados. Essa prática de fixação mecânica foi bastante utilizada no contexto educacional brasileiro durante o Regime da Ditadura, guiados pelo modelo tecnicista (LUKESI, 2003). Com o tecnicismo pedagógico pretendia-se gravar na consciência dos alunos durante as aulas de EMC as normas de condutas a serem interiorizadas como (auto)controle e praticadas naturalmente como bons hábitos na vida social. Como destaca Chervel (1990), o sucesso de uma disciplina escolar depende das qualidades dos exercícios que são veiculados a ela.

Em síntese, durante a Ditadura Civil-Militar, a disciplina e os livros de EMC disseminavam prescrições de hábitos, costumes, valores, virtudes, deveres e direitos. As orientações indicam um estágio civilizatório brasileiro marcado pela supremacia de poder dos códigos militares, dos princípios cristãos, da conservação da ideia de família tradicional e da segurança da propriedade daqueles bem dotados economicamente.

Para se perfilar aos ideais de homem civilizado, o indivíduo precisaria interiorizar um conjunto de códigos de comportamento e sentimentos como um mecanismo para autocontrolar as suas pulsões e emoções na vida em sociedade na qual a democracia era um eufemismo. Para isso, a cultura escolar com a disciplina e os livros de EMC era um lugar privilegiado de potencialização de formação da personalidade do indivíduo que deveria ser um "bom" cidadão brasileiro para um bom convívio nas configurações sociais.

\section{CONFIGURAÇÕES SOCIAIS PARA FORMAÇÃO DO HOMEM CIVILIZADO}

Os livros didáticos de EMC (FONTOURA, 1970; MICHALANY; RAMOS, 1970; MOSCHINI; COSTA; MUSSUMECI, 1970; ANDRADE, 1971; SANTOS, 1974; SIQUEIRA; BERTOLIN, 1981) revelam as principais instituições 
responsáveis pela formação do ideal de homem brasileiro: Estado, Escola, Família, Igreja e Forças Armadas. Estas tinham maior representatividade no contexto nacional da Ditadura Civil-Militar por serem entendidas como lugares de poder regeneradores e disseminadores dos bons princípios e valores, por isso estavam em posição de superioridade enquanto agrupamentos sociais. Elas foram enfatizadas nos livros didáticos como conteúdo obrigatório de ensino, inclusive preconizado nas diretrizes curriculares propostas pelo Conselho Federal de Educação (CFE) e pela Comissão Nacional de Moral e Civismo (CNMC).

As instituições supracitadas podem ser compreendidas, pela teoria de Elias (1980; 1994a; 2006), como configurações sociais formadas por indivíduos interdependentes que dissipam regras, costumes e relações de poder em nome dos ditos padrões civilizatórios. Isto porque indivíduo e instituição, indivíduo e sociedade são estruturas interdependentes que se constituem em interação, e ao passo que mudam as estruturas sociais mudam as estruturas psíquicas dos indivíduos, e assim reciprocamente. Então, aqui trataremos as instituições presentes nos livros de EMC como configurações sociais, pois os seus códigos de condutas estruturantes do social estavam interconectados com a esperada formação da personalidade do cidadão civilizado durante a Ditadura CivilMilitar.

O conteúdo Estado esteve presente nos livros de EMC como regulador da sociedade e modelador do homem conforme um padrão social, anulando interesses pessoais em virtude da suposta coletividade. Segundo Santos (1974), em Educação Moral e Cívica, a configuração Estado teria a responsabilidade de fiscalizar as demais instituições no intuito de salvaguardar o bem geral, uma vez que a ela fora atribuído o domínio e a soberania, e, para tanto, caber-lhe-ia o uso de seus núcleos de poder para manutenção da ordem.

Outros livros de EMC também apresentam a noção de Estado:

É a nação independente, isto é, soberana, sua maior finalidade é a ordem e a prosperidade social. Suas funções são reguladas por leis, 
definidas por sua força. A tarefa principal do Estado é durar. Seu objetivo final é manter-se. Sua moral é simples: Tudo o que for indispensável para sua existência é legítimo (MICHALANY; RAMOS, 1970, p. 66).

O Estado controla a sociedade, mas não é, e nem pode ser 'dono' da sociedade. Por isso, para que nossa sociedade possa cumprir sua finalidade que é o bem comum, o bem estar de todos os seus membros é indispensável que todos esses membros colaborem ajudando-se mutuamente e ajudem o Estado e o Governo (ANDRADE, 1970, p. 251).

O Estado enquanto configuração social exigia e clamava a participação recíproca dos membros da sociedade para legitimação de seu poder, soberania, ordem e legalidade em nome da prosperidade social e do presumido bem estar comum. No caso do Estado ditatorial vivido no Brasil (1964-1985), houve centralização de poder ainda maior enfraquecendo intensamente o sentimento de Estado democrático de direito, desequilibrando a balança de poder a favor de grupos que se posicionavam como referenciais de lideranças políticas, econômicas, militares e religiosas que faziam uso de princípios autoritários de governo. Entretanto, segundo Napolitano (2014), o Estado autoritário não queria personalizar o exercício do poder político, então permitia o exército rotinizar a autocracia, despersonalizar cargos e manter alguma unidade nacional.

Nesse cenário, a Escola, por sua vez, foi propagada nos livros de EMC como configuração social com forte responsabilidade pela formação da personalidade dos indivíduos da nova geração que se reconheceria no regime autoritário de governo. Ela é caracterizada, na obra Educação Moral, Cívica e Política (MICHALANY; RAMOS, 1970), como um lugar encarregado por transmitir os valores culturais, espirituais, políticos e sociais considerados imprescindíveis para a sociedade civilizada que se pretendia construir, unificar e viver em tempos de exceção (Fig. 4). 
Figura 4 - O papel da Escola.

A ESCOLA COMO
FATOR DE EDUCAÇAO
Já vimos que educação são todos aquêles processos que visam
transmitir aos jovens determinados conhecimentos e padrões de com-
portamento, a fim de garantir a continuidade da cultura da socie-
dade.
Automàticamente, êsses processos de transmissão determinam
algumas relaçes básicas entre pais e filhos, entre jovens e velhos, en-
tre mestres e discípulos. Se o patrimônio cultural a ser transmitido é
pequeno, as regras educacionais consistem às vêzes em atos rotinei-
ros, destinados principalmente a manter a autoridade dos mais velhos.
Garantida essa autoridade, a simples convivência das gerações se en-
carregará do restante.
Entretanto, em culturas mais adiantadas, as regras eduracionais
são mais complexas e exigem um sistema de conhecimentos especia-
lizados, necessários para garantir uma eficiente transmissão cultural.
Assim, o trabalho de educar deve ser sistematizado, selecionado; orien-
tado. Tais exigências obrigam à aquisição de um sistema de conheci-
mentos especializados, que só a escola pode oferecer.
ma.

Fonte: Michalany e Ramos (1971, p. 22).

A Escola era considerada uma das principais configurações sociais responsáveis pela transmissão dos modos de se pensar, ver o mundo e agir da sociedade brasileira idealizada no regime autoritário. Competia aos seus agentes a veiculação de códigos morais, cívicos e políticos em prol do fortalecimento da propaganda pra frente Brasil.

Pretendia-se por meio da Escola legitimar uma unidade nacional dando continuidade à cultura autoritária por meio de preceitos que induzissem à manutenção da ordem e do progresso social. Além da EMC a ser transmitida, tornava-se elementar o fortalecimento de lugares de relações de poder para manutenção da autoridade dos mais velhos, entre eles, os membros de famílias de bem.

A Família é uma configuração social composta por um grupo de indivíduos unidos em teias de interdependência por uma herança cultural, histórica, biológica e social comum, a qual se inclui um conjunto de códigos de comportamentos e sentimentos de civilidade, nem sempre livres de tensão. Essa configuração foi considerada nos livros de EMC o berço esplendido da sociedade brasileira, assim quanto mais valorosa fosse a noção de Família, mais valorosa 
seria a de Pátria. Enquanto formadora da sociedade de bem, caberia à ela a difusão de códigos comportamentais e morais aos seus novos membros dignos de civilidades.

Para Siqueira e Bertolini (1981), a Família seria responsável por transformar o homem em um ser social para viver em sociedade, pois nas relações familiares praticar-se-ia a educação dos bons modos exigidos para que os seus membros pudessem ser autocontrolados para de fato serem incluídos no meio social (Fig. 5). Tratavam-se de relações de poder intergeracionais, uma geração precedente estabelecendo censuras e pressões autorizadas no contexto autoritário afim de modelar hábitos de uma nova geração a ser obediente a aqueles em posição de superioridade hierárquica.

Figura 5 - Conteúdos sobre o papel da Família.

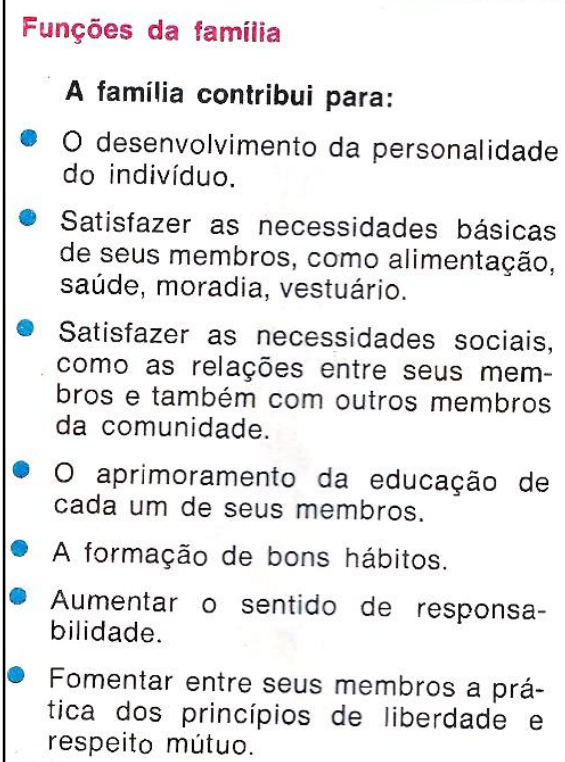

- Satisfazer as necessidades básicas de seus membros, como alimentação, saúde, moradia, vestuário.

- Satisfazer as necessidades sociais, como as relações entre seus membros e também com outros membros da comunidade.

- O aprimoramento da educação de cada um de seus membros.

- A formação de bons hábitos.

- Aumentar o sentido de responsabilidade.

- Fomentar entre seus membros a prática dos princípios de liberdade e respeito mútuo.

Fonte: Siqueira e Bertolin (1981, p. 115).

A Família era compreendida como a base da sociedade, um dos principais alicerces sociais, logo ela era imprescindível para a formação do considerado homem civilizado que se guiaria pelos exemplos das pessoas mais velhas de seu clã. Contudo, a sua representação iconográfica pouco se assemelhava ao perfil 
étnico predominante da população brasileira. Os livros de EMC veiculavam imagens de pessoas com traços étnicos de europeus e norte-americanos, brancos e felizes sem miséria socioeconômica (Fig. 6), enquanto a maioria da população era constituída de negros, mulatos, pardos e com baixa concentração de renda.

Figura 6 - Representação de família.

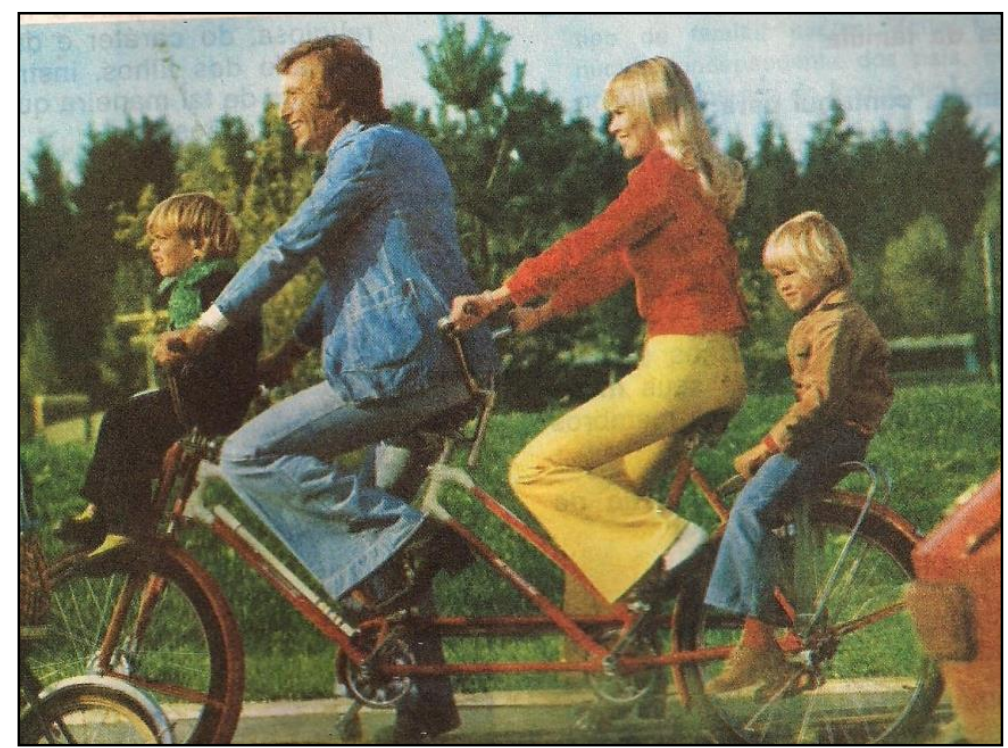

Fonte: Siqueira e Bertolin (1981, p. 117).

Michalany e Ramos (1970) registram que uma configuração familiar deveria ser constituída a partir da união matrimonial entre homem e mulher, genitores de filhos. Ela teria como agente central o pai detentor do pátrio-poder sobre os demais membros. Esse poder, segundo Moschini, Costa e Mussumeci (1970, p. 20), caracteriza-se pela autoridade do pai reconhecida em lei como chefe de família portador do direito e o dever de orientar e defender seus filhos e de reger e de governar as relações de seus membros: "A ele devem sujeitar-se a esposa e os filhos".

A Família de bem deveria se guiar pelos ordenamentos dos valores cristãos, logo tem-se a Igreja como uma forte configuração religiosa a ser compreendida, aceita e vivida pelas pessoas. Nos livros de EMC, a Igreja ocupa 
lugar de conteúdo a ser ensinado por ter posição prestigiada na promoção dos padrões de religiosidade e moralidade a serem transmitidos em prol da autoregulação dos sentimentos e valores da alma cultivada ao longo da história do povo brasileiro, sobretudo no Estado ditatorial.

Nos livros de EMC, a Igreja é retratada na maioria das vezes como sinônimo de configuração católica, tendo como principal referencial de homem, Jesus Cristo. Embora o Estado e Escola fossem considerados lugares laicos, o ensino de EMC se apoiava comumente no catolicismo e nas inspirações de Deus e seus sacerdotes para atingir a sua finalidade de preservação das tradições nacionais, do espirito religioso, da vida ordeira e da dignidade humana.

Em Princípios de Educação Moral e Cívica, Fontoura (1970) categoriza a Igreja como uma poderosa organização social de convívio e hierarquia em sociedade. No livro, constam Os Dez Mandamentos a serem ensinados nas escolas (Fig. 7).

Figura 7 - Os 10 mandamentos do cristianismo apresentados como conteúdo da disciplina de Educação Moral e Cívica (EMC).

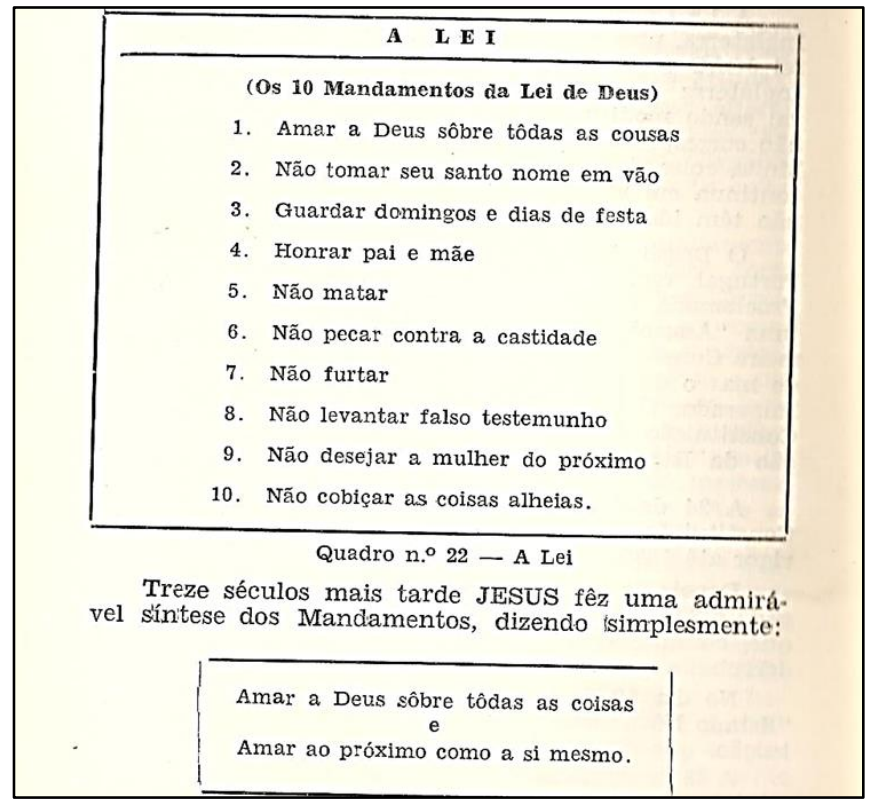

Fonte: Fontoura (1970, p. 245). 
O bom cidadão civilizado também cultivaria o amor e a sua ligação com o criador. A Igreja seria a configuração responsável por colocar os indivíduos num sistema de crenças, atitudes, sentimentos, desejos e esperanças ligado a um ser divino espiritual supremo. Ser civilizado era cultuar a alma e servir a Deus, tendoo como "o fim último do homem e que fora dele a vida é inútil e sem sentido" (MICHALANY; RAMOS, 1971, p. 102).

Com os livros de EMC intentavam-se transmitir nas escolas que a Igreja tem suas leis, suas normas e seus líderes a serem idolatrados, assim como em um regime político autoritário. A finalidade da EMC seria a de reproduzir a compreensão de que a Igreja contribui a longo prazo com o processo civilizador brasileiro no que diz à formação religiosa da personalidade dos indivíduos que deveriam viver em paz, harmonia, sem ódio, perdoando o próximo e venerando os líderes.

Além da Igreja, Família e Escola para potencializarem a formação da personalidade dos indivíduos rumo a um maior autocontrole das pulsões para se viver um padrão de civilidade e de ordem socialmente exigido pelo regime autoritário, as Forças Armadas também auxiliariam na missão. Segundo os seis livros de EMC analisados por nossa pesquisa, as Forças Armadas são configurações constituídas por militares permanentes e regulares do Exército, Marinha e Aeronáutica destinados à defesa da Pátria, do território, da população, dos poderes constitucionais e do cumprimento da lei. Essa configuração comandou o Estado brasileiro por um período de vinte e um anos a partir da instauração da Ditadura Civil-Militar em 1964.

No Estado autoritário, as Forças Armadas tornaram-se responsáveis pelo controle e censura dos indivíduos por intermédio do monopólio da violência legalizada e autorizada governamentalmente. Elas foram encarregadas por condicionar os comportamentos dos brasileiros segundo os valores e práticas cívicas, patrióticas e morais.

Sob a lógica de combate à ameaça subversiva e em nome da política de Segurança Nacional, as Forças Armadas se valeram do uso da força física e da 
disseminação do medo como artifícios para o controle da ordem no intuito do suposto bem comum. O medo assumira um papel de extrema relevância para a regulação dos indivíduos conforme um padrão comportamental forjado. O medo não fora mediado apenas pelo uso da violência, mas também pelas práticas de coerções psíquicas, entre elas cerceamento de liberdade de expressão, abolição de habeas corpus para crimes políticos, redução da autonomia de poder do judiciário.

Em Educação Moral e Cívica (MICHALANY; RAMOS, 1970), identificase a prerrogativa de controle e manutenção da ordem guiada pela política de Segurança Nacional. Para as Forças Armadas conseguirem legitimação social, almejava-se disseminar junto aos agentes escolares a representação de instituição militar forte que doutrinaria moralmente, desenvolveria o patriotismo e faria cumprir os deveres (Fig. 8).

Figura 8 - Forças Armadas como fator de Educação.

\section{4 \\ AS FÔRÇAS ARMADAS COMO FATOR DE EDUCAÇÃO}

As Forças Armadas, assim como o lar e a escola, desempenham um importante papel na educação. Elas instruem militarmente e edueum moralmente o cidadão.

A instrução militar tem como objetivo principal a preparação do eidadîo para a guerra. A educação moral, que é a base da instrução militar, destina-se a elevar as almas, a desenvolver a idéia de Pátria, a formar o caráter e, sobretudo, a incutir no espírito do homem a concepçăo do esfôrço e do dever, do devotamento e do sacrifício à causa comum. Ela prepara o espírito do soldado para os misteres de sua elevada missão, tornando-o cumpridor fiel e consciente de seus deveres, e não uma simples máquina destinada a obedecer e executar.

Da convivência na caserna nasce o espírito de camaradagem entre os soldados. Assim, o corpo de tropa fica sendo uma grande família: ali se aprende a amar a Pátria, a conhecer a necessidade da subordinação aos superiores, a obedecer voluntàriamente, a respeitar a moral e a disciplina. Dessa forma, o militar virá a ser um bom soldado, bom filho, bom chefe de família e bom patriota.

Fonte: Michalany e Ramos (1971, p. 23).

As Forças Armadas foram propagandeadas nos livros didáticos como 
configuração de militares imbuída de forte gradiente de poder para manutenção da ordem, da disciplina do cidadão e da preparação do sentimento patriótico no cumprimento fiel e consciente das leis e da defesa dos valores nacionais. A consciência militarizada a ser interiorizada conduziria o cidadão à condição de bom filho, chefe de família e patriota.

Os livros de EMC veiculavam a representação de Forças Armadas como regeneradoras da nação e promotoras do zelo da educação moral e patriótica. As práticas de devotamento e sacrifício à causa supostamente comum elevariam o sentimento de "bom" homem civilizado brasileiro. Como uma das estratégias, a obrigatoriedade do serviço militar e os seus benefícios educativos compunham as orientações impressas nos livros de EMC. Como destaca Choppin (2004), os livros didáticos apresentam em sua estruturação um conjunto de preceitos considerados necessários a serem transmitidos às novas gerações.

\section{CONSIDERAÇÕES FINAIS}

A disciplina de Educação Moral e Cívica (EMC), durante a Ditadura CivilMilitar no Brasil, teve por finalidade disseminar códigos de comportamentos e sentimentos para a formação da personalidade da nova geração escolarizada em interdependência com o fortalecimento das estruturas políticas e sociais que tratavam a democracia como um eufemismo. Idealizava-se formar escolares que obedecessem as rígidas regras governamentais, sociais, militares e religiosas, para que assim eles pudessem ser considerados "civilizados" e dignos de viver num país potência em termos de Segurança e Desenvolvimento Nacional. Para tanto, os livros didáticos de EMC foram considerados um dos principais instrumentos difusores de valores culturais, políticos, cívicos e morais nas escolas.

Na pesquisa seis livros didáticos de EMC foram analisados: Fontoura (1970); Michalany e Ramos (1970); Moschini, Costa e Mussemeci (1970); 
Andrade (1971); Santos (1974); e Siqueira e Bertolin (1981). Eles revelam que os ideais de homem civilizado são identificados em seus conteúdos que têm por finalidade versar sobre as relações de interdependência entre a formação da personalidade do bom cidadão (Valores e Virtudes, Direitos e Deveres, Hábitos e Costumes) e a constituição de configurações sociais (Família, Escola, Igreja, Forças Armadas, Estado Nacional).

O homem civilizado, para Fontoura (1970), seria cívico com personalidade moldada na moral e nos bons costumes, no respeito às autoridades e à ordem. Michalany e Ramos (1970) entendem o homem civilizado como aquele seguidor da tradição, defensor da unidade e da soberania nacional. Moschini, Costa e Mussemeci (1970) consideravam civilizado aquele detentor de caráter formado nas virtudes, fiel a Deus e à Pátria, sendo um cidadão consciente da sua responsabilidade para solucionar os problemas dos país. Andrade (1971) defendia a imagem de homem patriota, envaidecido dos prodígios nacionais, respeitoso às instituições e tradições, bem como partícipe do futuro do país através do "suor" de seu trabalho. Segundo Santos (1974), o homem civilizado cumpriria fielmente seus deveres respeitando às autoridades, valorizando a memória, a história e os símbolos nacionais, e ele seria atento com os seus hábitos e valores, colaborando assim na realização das aspirações da Pátria. Para Siqueira e Bertolin (1981), o homem civilizado cumpriria seus deveres no trabalho, na escola, na comunidade e na Pátria, tal homem teria a necessidade social de boas maneiras e costumes, e demandaria apreço pela religiosidade e pelas instituições.

Por fim, os ideais de homem civilizado veiculados nos livros de EMC convergiam à personalidade de ser trabalhador resignado, cristão, membro de uma família ligada pelo matrimônio, servidor da Pátria, pagador de impostos, obediente às normas de segurança, respeitador daquilo que era censurado, submisso aos seus superiores governantes em diferentes instituições. Para o bom convívio na suposta sociedade do bem comum, o homem civilizado que se queria forjar no regime autoritário civil-militar seria aquele controlador de suas emoções e pulsões num sentido de manter falseada a ordem democrática da vida 
em sociedade e o otimismo com o progresso da nação. Todavia, muitas configurações sócias de resistências ao regime autoritário existiram no período, o que é tema para uma outra pesquisa.

\section{REFERÊNCIAS}

ABREU, Vanessa Kern de. A educação moral e cívica: disciplina escolar e doutrina disciplinar - Minas Gerais (1969-1993). 2008. 160 f. Dissertação (Mestrado em Ciências Humanas) - Universidade Federal de Uberlândia/UFU, Uberlândia/MG, 2008.

ALMEIDA, Djair Lázaro de. Educação Moral e Cívica na ditadura militar: um estudo de manuais didáticos. 2009. 182 f. Dissertação (Mestrado em Educação) - Faculdade de Educação, Universidade Federal de São Carlos/Ufscar, São Carlos/SP, 2009.

BITTENCOURT, Circe. Ensino de história: fundamentos e métodos. São Paulo: Ed. Cortez, 2004.

BRASIL. Comissão Nacional de Moral e Civismo. Subsídios para Currículos e Programas Básicos de Educação Moral e Cívica. Prescrições sobre currículos e 3385 programas básicos de Educação Moral e Cívica nos três níveis de ensino: (Artigo $4^{\circ}$ do Decreto-Lei n. 869/69). Brasília, 1970.

BRASIL. Decreto-Lei n. 59.355, de 4 de outubro de 1966.

BRASIL. Decreto-Lei n. 68.065, de 14 de janeiro de 1971a.

BRASIL. Decreto-Lei n. 869, de 12 de setembro de 1969.

BRASIL. Parecer do CFE n. 94, de 4 de fevereiro de 1971b.

CHARTIER, Roger. A história cultural: entre práticas e representações. Lisboa: Difel, 1990.

CHERVEL, André. História das disciplinas escolares: reflexões sobre um campo de pesquisa. Teoria \& Educação, Porto Alegre, v. 2, p. 177-229, 1990.

CHOPPIN, Alain. História dos livros e das edições didáticas: sobre o estado da arte. Educação e Pesquisa, v. 30, n. 3, p. 549-566, set./dez. 2004.

CUESTA FERNÁNDEZ, Raimundo. Sociogenesis de una disciplina 
escolar: la historia. Barcelona: Ediciones Pomares-Corredor, 1997.

CUNHA, Luiz Antônio; GÓES, Moacyr. O golpe na educação. Rio de Janeiro: Jorge Zahar, 2002.

DREIFUSS, René Armand. 1964 - a conquista do Estado: ação política, poder e golpe de classe. Petrópolis: Vozes, 1986.

ELIAS, Norbert. A sociedade dos indivíduos. Rio de Janeiro: Jorge Zahar, 1994a.

ELIAS, Norbert. Escritos \& ensaios. Estado, processo, opinião pública. Rio de Janeiro: Jorge Zahar, 2006.

ELIAS, Norbert. Introdução à sociologia. Lisboa: Edições 70, 1980.

ELIAS, Norbert. O processo civilizador: formação do Estado e civilização. Rio de Janeiro: Jorge Zahar, 1993.

ELIAS, Norbert. O processo civilizador: uma história dos costumes. Rio de Janeiro: Jorge Zahar Ed., 1994b.

FICO, Carlos. Versões e controvérsias sobre 1964 e a ditadura militar. Revista Brasileira de História da Educação, São Paulo, v. 24, n. 47, 2004.

FILGUEIRAS, Juliana Miranda. A Educação Moral e Cívica e sua produção didática (1969-1993). 2006. 222 f. Dissertação de Mestrado (Educação: História, Política e Sociedade) - Pontifícia Universidade Católica de São Paulo/PUC-SP, São Paulo/SP, 2006.

FONSECA, Selva Guimarães. Caminhos da história ensinada. Campinas: Papirus, 1993.

GOODSON, Ivor F. A construção social do currículo. Lisboa: Educa, 1997. GOODSON, Ivor F. Currículo: teoria e história. Petrópolis: Vozes, 1995.

JULIA, Dominique. A cultura escolar como objeto histórico. Tradução Gizele de Souza. Revista Brasileira de História da Educação, n. 1, p. 09-43, jan./jun. 2001.

LUKESI, Cipriano Carlos. Filosofia da educação. São Paulo: Cortez, 2003.

MOREIRA, Kenia Hilda; DIAZ, José Maria Hernandez (org.). História da educação e livros didáticos. Campinas: Pontes Editores, 2017.

MORENO, Jean Carlos. Quem somos nós? Apropriações e representações 
sobre a(s) identidade(s) brasileira(s) em livros didáticos de história (1971-2011). Jundiaí, SP: Paco Editorial, 2014.

MUNAKATA, Kazumi. Livro didático como indício da cultura escolar. História da Educação, Porto Alegre, v. 20, n. 50, p. 119-138, set./dez. 2016.

NAPOLITANO, Marcos. 1964: história do regime militar brasileiro. São Paulo: Editora Contexto, 2014.

REIS, Daniel Aarão. Ditadura e democracia no Brasil: do golpe de 1964 à Constituição de 1988. Rio de Janeiro: Zahar, 2014.

REZENDE, Maria José de. A ditadura militar no Brasil: repressão e pretensão de legitimidade, 1964-1984. Londrina: Eduel, 2013.

VIÑAO FRAGO, Antonio. A história das disciplinas escolares. Revista Brasileira de História da Educação, n. 18, p. 173-205, set./dez. 2008.

\section{FONTES HISTÓRICAS}

ANDRADE, Benedito de. Educação Moral e Cívica. 2. ed. revista e aumentada. São Paulo: Editora Atlas, Curso médio, 1971.

BERTOLIN, Rafael; SIQUEIRA, Antônio de. 1. ed. Atividades de Educação Moral e Cívica. São Paulo: Ibep, 1981.

FONTOURA, Amaral. Princípios de Educação Moral e Cívica. 1. ed. Rio de Janeiro: Editora Aurora, 1970.

MICHALANY, Douglas; RAMOS, Ciro de Moura. Educação Moral, Cívica e Política. 1. ed. São Paulo: Editora Michalany, 1970.

MOSCHINI, Felipe N.; COSTA, Otto; MUSSUMECI, Victor. Moral e Civismo. 11. ed. São Paulo: Editora Brasil Ebsa, 1970.

SANTOS, Theobaldo Miranda. Educação Moral e Cívica. 6. ed. São Paulo: Companhia Editora Nacional,1974. 
DANIELE CRISTINA FREDIANI GUSMÃO é mestre em Educação pela Universidade Estadual de Londrina (UEL). Graduada em História e Ciência da Religião pela Universidade Estadual do Norte do Paraná (UENP) e em Letras pela Universidade Estadual de Ponta Grossa (UEPG).

E-mail: dnlfrediani@gmail.com

(ib) http://orcid.org/0000-0002-7272-1662

TONY HONORATO é pós-doutor, doutor e mestre em Educação. Licenciado em Educação Física. Atualmente é docente do Programa de Pós-Graduação em Educação da Universidade Estadual de Londrina (UEL).

E-mail: tonyhonoratu@gmail.com

(b) http://orcid.org/0000-0003-3057-1157

Recebido em: 06 de maio de 2018

Aprovado em: 12 de janeiro de 2019

Revista História da Educação - RHE

Associação Sul-Rio-Grandense de Pesquisadores em História da Educação - Asphe

Artigo de acesso aberto distribuído nos termos de licença Creative Commons. 